\title{
伝統町家の保存再生に適した軒 裏防火仕様の開発
}

\section{DEVELOPMENT OF BARE-TIMBER EAVES FOR THE RESTORATION OF HISTORIC TOWN BUILDINGS COMPATIBLE WITH THE CURRENT BUILDING STANDARD LAW}

\begin{tabular}{|c|c|}
\hline 美—— & 安井 昇 \\
\hline 長谷見雄二—* & 木村忠紀 — $* 4$ \\
\hline
\end{tabular}

キーワード

町家再生，化粧軒裏，防火構造，遮熱性，遮炎性

Keywords:

Restoration of traditional townhouses, Bare timber eaves, Fire protective construction, Thermal insulation, Integrity

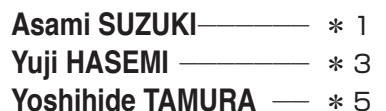

Noboru YASUI $-* 2$
Tadanori KIMURA $-* 4$
Naoya KADOOKA $-* 6$

8 designs of traditional style bare timber eaves reinforced with conventional building materials to block penetration of an external fire into the building are proposed for the restoration and renovation of historic townhouses in Kyoto. The full scale fire resistance tests on the integrity and the thermal insulation of these designs against external fires revealed that these designs should be rated as either Fire Protective Construction or 45-60min Quasi-fireproof Construction.

\section{1. はじめに}

京都をはじめとする歴史的市街地では伝統的木造建築が準防火地 域内に集積している場合が多く、これら木造建築において軒裏を介 した延焼防止性能を確保することは都市防災上、重要課題である。

筆者らは垂木、面戸板、野地板等の構成部材を木現しとした京町家 様式の化粧軒裏について研究開発 1)を行い、その成果の一部は H12 建設省告示第 1358 号及び 1380 号に準耐火構造（45 分及び 1 時間） の化粧軒裏仕様として追加された（表 3)。これらを用いる事で、準 防火地域でも防火性能の高い木現し化粧軒裏の設計が可能となった。

しかし、告示仕様では野地板を $30 \mathrm{~mm}$ 以上にする必要があり、既 存京町家の一般的寸法 9 12mm よりも大きい上、既存垂木に面戸欠 き等の処置を施す必要がある為、その活用は新築時や屋根全体を作り 直寸大規模な改修時に限定される。もともと、準防火地域内において 2 階建以下、延床面積 $500 \mathrm{~m}^{2}$ 以下であれば軒裏は防火構造とすれば良 く、それは告示の準耐火構造仕様よりも軽微な仕様で実現できる可能 性がある。既存町家の改修は現在も多く行われており、多種多様な仕 様・劣化が見られる既存町家の防火性能を効率的に向上させる為には、 居ながら改修や瓦の莫き替え時に併せた改修等、改修パターンに応じ

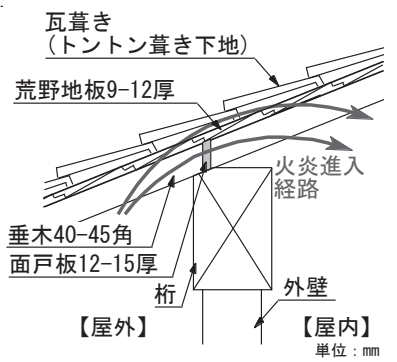

図 1 化粧垂木型式の軒裏断面

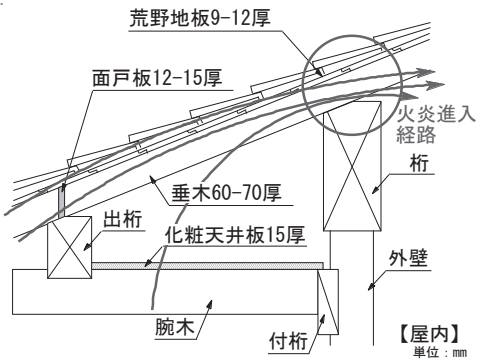

図 2 加敷造りの軒裏断面
た簡易的な防火改修仕様の開発が必要と考えられる。

同様な課題は全国の歴史的市街地で認められるが、なかでも京町 家は棟数が多く、再生・改修の潜在的市場が大きい。その上、部材 断面が比較的小さく、他地域の町家に比べて防火的に不利である為、 京町家を基準に防火的法適合を達成できれば、他地域へも応用が可 能であると考えられる。そこで本報では、既存京町家の小規模改修 までを視野に入れて防火構造以上の性能を有する木現し化粧軒裹を 設計し、実大部材加熱実験により、その性能を確認する。

\section{2. 既存京町家の軒裏の一般仕様}

京町家はツシ 2 階建てと本 2 階建てに大別され、2 階大屋根の化 粧軒裏はツシ 2 階建ては化粧垂木型式（図 1）が、また本 2 階建て は加敷造り（図 2）が多い。ツシ 2 階建ては 2 階の階高を低く抑え た建物の為、2 階は天井を張らずに納戸等に利用される場合が多く、 小屋裏の屋内施工は比較的容易である。一方、現存する町家は本 2 階建てが多く、2 階居室には天井を設ける場合が多く、また小屋裏 部分の天井懐が狭いため、直下の居室の天井板を取り外さないと小 屋裏の屋内施工は難しい。

既存京町家では施工年代や施工者により若干の差はあるが、化粧 垂木型式の部材寸法は、概ね、垂木が 40～45mm 角、面戸板が 12 〜 $15 \mathrm{~mm}$ 、野地板が 9〜12mm（小屋裏部分はばら打ち、化粧軒裏 は詰め打ち)で、屋根はトントン莫き下地に瓦を敷いた仕様となる。 桁はトカド欠き（桁を端から端まで勾配なりに落とす仕様）を施す ことが多い。木材厚が薄いと屋内側に火炎貫通しや寸く、屋内一の 延焼経路としては面戸板部と野地板上部が考えられる 1)。

一方、加敷造りは、外壁に腕木 ・ 出桁をつけて軒の出を深くした

本稿は 2010 年度及び 2011 年度日本建築学会大会 ${ }^{344}$ で口頭発表した。

早稲田大学大学院創造理工学研究科 大学院生

（干 169-8555 東京都新宿区大久保 3-4-1）

早稲田大学理工学研究所 客員研究員・博士 (工学)

早稲田大学建築学科 教授・工博

京都府建築工業協同組合 副理事長

関西木造住文化研究会 代表幹事

財日本建築総合試験所 研究員

Graduate Student, Waseda Univ.

Visiting Researcher, RISE, Waseda Univ., Ph. D.

Prof., Waseda Univ., Dr. Eng.

Vice President, Kyoto Cooperative Union of Carpenters

Secretariat, Kansai Association for Research in Traditional Housings

Researcher, General Building Research Corporation of Japan 
化粧天井板付きの軒裏であるが、建築基準法上の軒裏の防火性能 は外部火災に対して外壁線から屋内側への延焼の有無によって判断 される為、軒裏としての防火性能を確保寸るには化粧垂木型式と同 様に桁上部からの延焼経路を塞ぐように補強すればよい（図 2)。

\section{3. 試験体の設計方針}

化粧軒裏に求められる遮熱性と遮炎性を確保するには、図 1 及び 図 2 に示寸ような延焼経路となる面戸板部と野地板上部を防火的に 補強すればよい事が既往実験 1)よりわかっている。既存町家の改修 では、改修の程度によって解体する部材や施工方法が異なるため、 それに応じた補強方法を開発する必要がある。

\section{1 化粧軒裏の改修方法}

既存京町家の改修方法を、施工条件に応じて(1)～(3)の三通り検討 する（表 1 ）。なお、屋外側の野地板及び垂木の下面、面戸板の屋外 側に補強することも可能だが、垂木を現しとする軒下の意匠性を考 慮し、軒裏外観に影響しない範囲の改修のみを検討した。

(1) 屋内側からの改修

室内に天井板がある場合は補強範囲の天井板を取り外し、野地 板及び面戸板に対して室内側から施工寸る。

(2) 瓦の葺き替えに併せた屋外からの改修

瓦の莫き替えに合わせて既存野地板の上面を補強する。また、 同時に野地板を部分的に取り外すことで面戸板の補強を行う。

(3) 屋根全体を解体する大規模改修

屋根の大規模改修を行う場合は、野地板、面戸板を取り替える。

\section{表 1 化粧軒裏の改修方法の考え方}

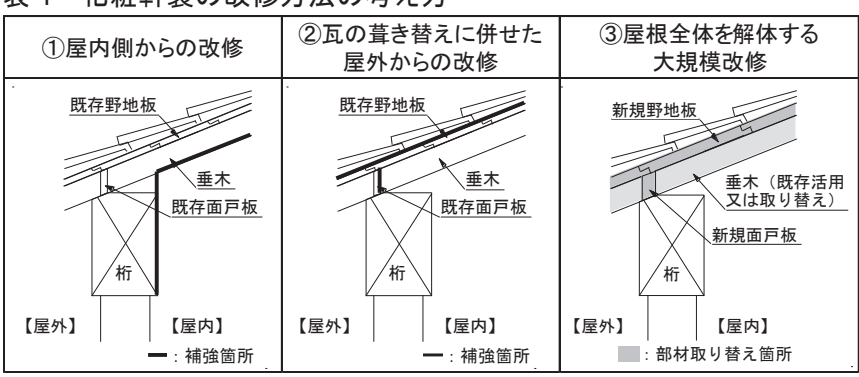

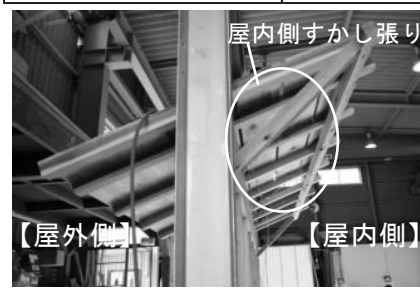

写真 1 試験体 A 軒裏部 3150

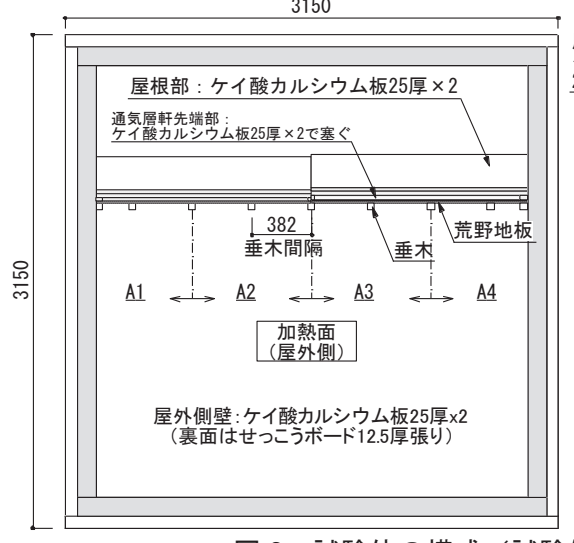

図 3 試験体の構成（試験体 A）
また、垂木が傷んでいる場合は垂木も交換する。

\section{2 試験体の設計}

上記の (1) (3)の改修方法について防火構造（耐火加熱 30 分の遮 熱性・遮炎性）2の達成を目標に試験体を計 3 体 8 仕様設計した。 まず試験体 A で既存の面戸板や野地板各部に補強を施し、補強仕様 の違いが延焼防止性能に与える影響を検討する。試験体 B・C では 試験体 $\mathrm{A}$ の結果を踏まえ、意匠性・施工性の向上可能性を検討寸る。 なお、試験体仕様はいずれも既存京町家及び在来軸組木造一般に使 われている材料によるオープン工法で設計した。

\section{4. 試験体概要}

\section{1 試験体設計の共通事項}

試験体概要を表 2 に示す。試験体は防火性能を確認したい軒部分 （垂木、野地板、面戸板）を再現し、それ以外は性能評価の試験 2) に準拠して、屋外側をケイ酸カルシウム板 $25 \mathrm{~mm}$ 厚 2 枚張り、屋内 側をせっこうボード $12.5 \mathrm{~mm}$ 厚で覆った壁状とし、屋根莫き材は瓦 では落下し炉を損傷させる恐れがあるため、ケイ酸カルシウム板 $25 \mathrm{~mm}$ 厚の 2 枚張りで代用した。このとき、瓦屋根に納まり上生じ る瓦と野地板の隙間を再現するため、野地板上部に $25 \mathrm{~mm}$ の通気層 を設け、瓦莫きの実状に近くなるよう軒先をケイ酸カルシウム板 (漆 喰の代用）で、上部をセラミックファイバー（のし瓦、漆喰の代用） で塞いだ。面戸板や野地板は改修前の既存部材が利用されることを 想定し、既存京町家の一般仕様を基に寸法を決定した。屋根は瓦屋 根を想定して 4 寸勾配とし、屋根莫き材はトントン莫き下地を想定 し、野地板屋外側は板同士を合いじゃくり加工（12mm 厚 $\times$ 働き巾 $165 \mathrm{~mm}$ ) で詰め張りした。野地板屋内側は小屋裏のばら打ちを再現 し、燃え抜け防止上危険側となるよう木材 $(12 \mathrm{~mm}$ 厚 $\times$ 幅 $180 \mathrm{~mm})$ を桁屋内側表面直上から $15 \mathrm{~mm}$ の隙間を空けたすかし張りとした (写真 1 、図 6•7)。面戸板は木材 $12 \mathrm{~mm}$ 厚とし、垂木の面戸じゃく りは設けなかった。垂木は木材 $45 \mathrm{~mm}$ 角、間隔 $382 \mathrm{~mm}$ とし、桁は 屋根勾配（4 寸勾配）に合わせたトカド久きとした。木材は既存京 町家の一般的な材種を考慮し、面戸板・野地板・垂木はスギを、桁は アカマツが多いが、短期間での材料調達が容易なベイマツを用いた。

\section{2 各試験体の詳細}

\section{(1) 試験体 $A$}

試験体外寸を W $3150 \mathrm{~mm} \times \mathrm{H} 3150 \mathrm{~mm}$ とし、垂木部で野地板及び 面戸板の仕様を分け（図 3)、計 4 仕様について遮熱性・遮炎性を検 証できるようにした。各仕様の断面詳細を図 6 に示す。
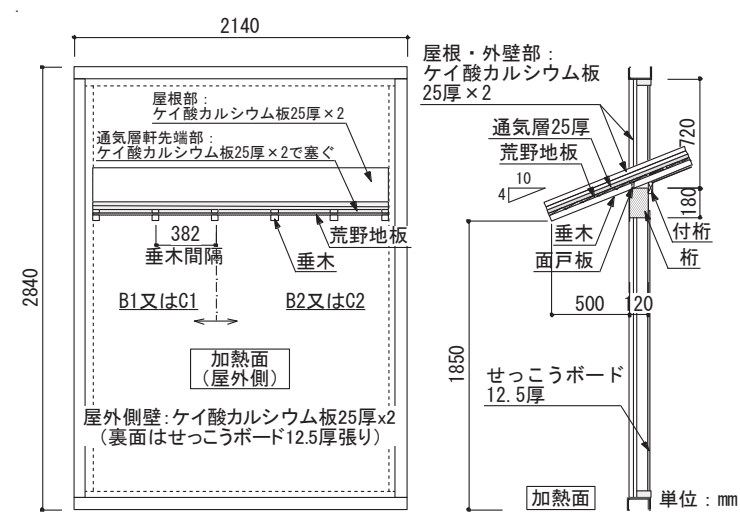

図 4 試験体の構成（試験体 B · C ) 


\section{(1) A1、A2（屋内施工を想定）}

屋内施工を想定し、室内側から面材を各部に張り付けた。A1 は垂木間に木下地を設け、垂木が現しとなるよう強化せっこうボ ード $12.5 \mathrm{~mm}$ 厚を垂木間に張った。A2 は断熱改修を考慮して垂 木間にグラスウール(密度 $10 \mathrm{~kg} / \mathrm{m}^{3}, 50 \mathrm{~mm}$ 厚) を充填し、せっこ うボード $12.5 \mathrm{~mm}$ 厚を垂木と桁を覆うように張った。

(2) A3、A4（屋外施工を想定）

両仕様とも屋根上からの施工を想定し、既存野地板 $12 \mathrm{~mm}$ 厚 （室内側すかし張り）の上面に木材 $12 \mathrm{~mm}$ 厚（働き巾 $165 \mathrm{~mm}$ 、 合いじゃくり加工）を全面詰め張りとした。また、既存面戸板 $12 \mathrm{~mm}$ 厚の屋内側にも補強を行い、A 3 は砂漆喰 $20 \mathrm{~mm}$ 厚塗り(ひ げこを使用)、A4 は木材 $30 \mathrm{~mm}$ 厚を増し張りした。

\section{（2）試験体 B （B1、B2 屋内施工を想定）}

試験体 $\mathrm{A}$ の結果を踏まえ、室内側からの改修に対して屋根の断熱 改修を行う場合を中心に、桁の室内側を見せるなど室内からの意匠 性と防火性を兼衫た仕様を設計した。試験体外寸を W2140mm × $\mathrm{H} 2840 \mathrm{~mm}$ とし、中央の垂木の左右で仕様を分けた（図 4)。

各仕様の断面詳細を図 7 に示す。垂木間にグラスウール(密度 $10 \mathrm{~kg} / \mathrm{m}^{3}, 50 \mathrm{~mm}$ 厚) を充填し、天井仕上げ材を垂木下端に張った。 試験体 A では桁下部まで面材を張っており、室内側の桁が隠れるた め、試験体 B では室内側の桁が現しとなるよう切り久きを設けた付 桁 $30 \mathrm{~mm}$ 厚を見切り材として桁に打ちつけ、天井仕上げ材をはめ込 んだ。天井仕上げ材は B1 はせっこうボード $12.5 \mathrm{~mm}$ 厚、B2 は木 材 $15 \mathrm{~mm}$ 厚（幅 $180 \mathrm{~mm}$ 、突き付け）とした。屋根莫き材や野地板、 面戸板、垂木は試験体 A と共通とした。

\section{（3）試験体 C}

屋根草き材と野地板を解体する大規模改修や新築を想定した防火 構造の化粧軒裏仕様を検討した。また、妻側ケラバ部の軒裏と外壁の 取り合い部を想定した仕様も設計し、防火構造の達成を目指す。試験 体 B と同様、試験体外寸を $\mathrm{W} 2140 \mathrm{~mm} \times \mathrm{H} 2840 \mathrm{~mm}$ とし、中央の垂 木の左右で仕様を分けた（図 4)。各仕様の断面詳細を図 8 に示す。 (1) C1（大規模改修及び新築を想定）
国土交通省告示の準耐火構造（45 分）の仕様は野地板 $30 \mathrm{~mm}$ 厚以上、面戸板 $45 \mathrm{~mm}$ 厚以上であり、防火構造を想定した場合、 より簡易な仕様で性能を確保できると考えられ。既往研究 1)にお いて、面戸板が $30 \mathrm{~mm}$ 厚の場合 27 分程度で面戸板付近より火炎 貫通したことを踏まえ、30 分以上の性能確保を前提に面戸板の寸 法は告示仕様の $45 \mathrm{~mm}$ 厚とした。また、野地板に関しては木材 $12 \mathrm{~mm}$ 厚では加熱 20 分で屋内側に燃え抜けたため 1)、上部通気層 を通じた屋内への再燃え抜けを 30 分以上抑制できるよう木材 $18 \mathrm{~mm}$ 厚（働き巾 $165 \mathrm{~mm}$ 、合いじゃくり加工）を全面詰め張り とした。また、面戸板と垂木・桁の接合部からの火炎貫通を防ぐ 為、図 5 のように垂木に面戸久き（幅 $45 \mathrm{~mm}$ 、深さ $5.5 \mathrm{~mm}$ ）を設 けると共に、垂木と桁の接合部の長さを既存京町家よりも深く取 り、桁芯（表面より $60 \mathrm{~mm}$ ）までトカド久きを設けた。

(2) C2（化粧垂木型式の軒裏ケラバ部分、板倉造りを想定）

伝統構法の一つである板倉造り（落とし込み板壁を含む）には垂 木を介さずに桁に野地板を直接張る仕様が見られ、同様の納まりは 京都等の伝統的町家の妻側ケラバ部にも見られる。そこで、C2 で は垂木や面戸板を設けず、野地板のみで 30 分の防耐火性能を確 保する仕様を設計した。火炎の侵入経路となる隙間を防ぐため、 桁芯（表面より $60 \mathrm{~mm}$ ）までトカド久きを施した桁に、野地板を 直に打ちつけた。C1 では屋内への再然え抜けを 30 分以上抑制す るため木材 $18 \mathrm{~mm}$ 厚を用いたが、本仕様では垂木を用いないため、 野地板のみで屋根莫き材の荷重を支持すること（支持スパン $1000 \mathrm{~mm}$ 程度) を考慮し、野地板は木材 $24 \mathrm{~mm}$ 厚 (働き巾 $165 \mathrm{~mm}$ 、 合いじゃくり加工）を全面詰め張りとした。

\section{5. 実験方法}

\section{（1）加熱方法}

実験は日本建築総合試験所の壁炉を用い、軒裏防火構造の性能評 価の方法 2)に準拠して、ISO834 標準耐火加熱曲線に沿った片面加 熱を非載荷で行った。加熱時間は 30 分（防火構造）を目標とし、 30 分経過後も試験体非加熱面への火炎貫通がない限り、60 分を限 度として加熱を継続した。加熱終了後は速やかに注水消火を行った。

表 2 試験体仕様及び実験結果一覧

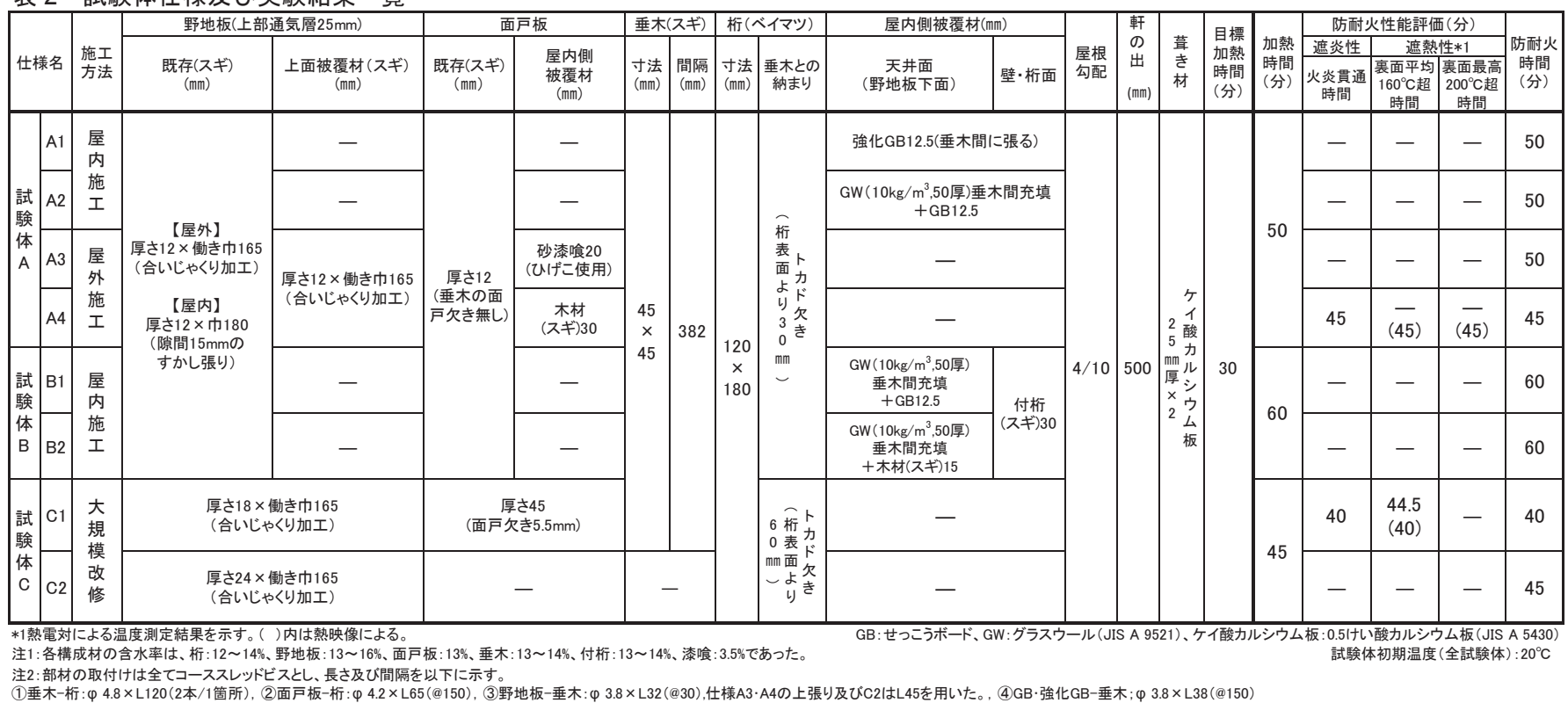

2:部材の取付けは全てコーススレッドビスとし、長さ及び間隔を以下に示す。

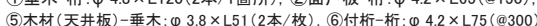




\section{（2）測定項目}

炉内と試験体内部の温度測定のほか、目視観察、試験体非加熱面 の熱映像撮影、各部材の炭化深さを測定した。また、試験体に用い る材料の含水率は、木材は $15 \%$ 以下、砂漆喰は $5 \%$ 以下を目標に調 整した。各部材ごとの含水率を表 2 欄外の注 1 に示す。

\section{（3）防耐火性能の評価}

軒裏の防耐火性能評価基準は性能評価機関の業務方法書 2)になら い、以下の 2 点とし、いずれかに達した時間を防耐火時間とした。

(1) 遮炎性: 非加熱面への火炎貫通が無い事（目視により確認）。

(2) 遮熱性：非加熱面温度が平均温度（初期温度 $\left(20^{\circ} \mathrm{C}\right)+$ $140^{\circ} \mathrm{C}=160^{\circ} \mathrm{C}$ )、又は最高温度（初期温度 $\left(20^{\circ} \mathrm{C}\right)+180^{\circ} \mathrm{C}=200^{\circ} \mathrm{C}$ ) に達しない事(熱電対と熱映像により確認)。

\section{6. 実験結果及び考察}

表 2 に実験結果一覧を、図 6〜8 に各試験体の加熱終了後の炭化 状況を示寸。切断面は垂木間の中央部とした。全仕様とも目標加熱 時間 30 分を上回り、試験体 B (B1,B2) は 60 分、試験体 $\mathrm{A}$ のうち $\mathrm{A} 1, \mathrm{~A} 2, \mathrm{~A} 3$ は 50 分、試験体 $\mathrm{A}$ の $\mathrm{A} 4$ と試験体 $\mathrm{C}$ の $\mathrm{C} 2$ は 45 分、 $\mathrm{C} 1$ は 40 分の遮熱性及び遮炎性を有することを確認できた。また、化 粧軒裏の典型的な延焼経路は野地板上部と面戸板部であるが 1)、火 炎貫通部位は A4 では野地板裏面、C1 では面戸板部であった。全仕 様の非加熱面温度推移を図 9 に、以下に詳細を示す。

\section{(1) 試験体 A}

加熱 45 分時に $\mathrm{A} 4$ の既存野地板裏面の隙間部（図 6,A4 の熱電 対設置点とは異なる位置）から火炎貫通したため、安全性を考慮 して 50 分時に加熱を終了した。試験終了まで、A4の面戸板室内 側（A4-4)）及び、A1,A2,A3 の室内側温度 (A1·A2-(5),A3-4) が $98^{\circ} \mathrm{C}$ に留まり、遮熱性の規定を超えなかった（図 9 )。

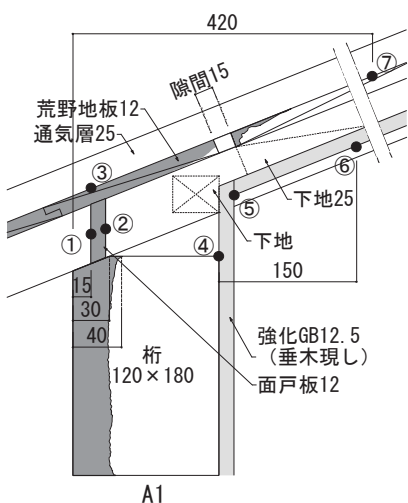

420
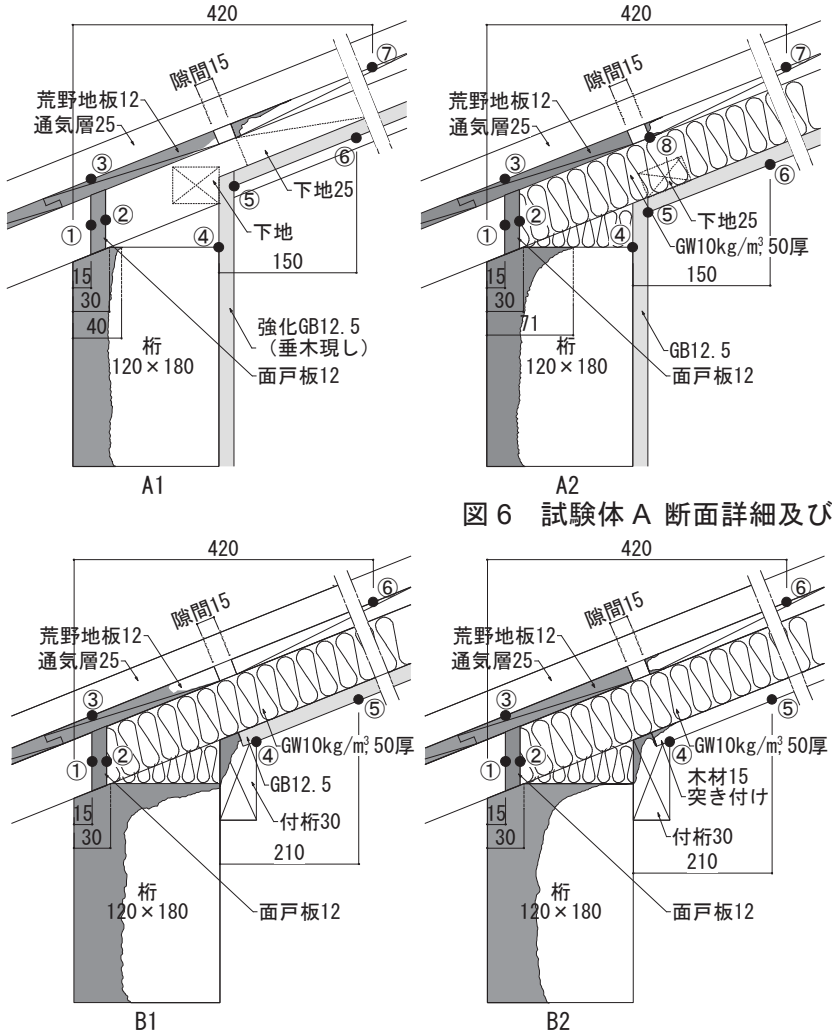

図 6 試験体 A 断面詳細及び炭化状況（加熱時間 50 分）

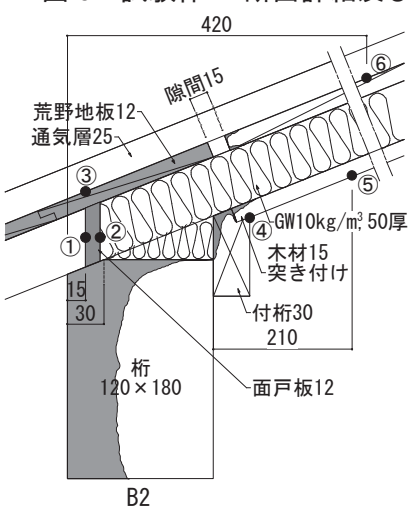

図 7 試験体 B 断面詳細及び炭化状況（加熱時間 60 分）

\section{(2) 試験体 B}

加熱終了 60 分時まで垂木周辺からの燃え抜けは確認されず、 両仕様の面戸板及び野地板の室内側温度（B1・B2-(4)）は $97^{\circ} \mathrm{C} に$ 留まり、遮熱性の規定を超えなかった（図 9)。

\section{(3) 試験体 C}

加熱 40 分時に $\mathrm{C} 1$ の面戸板と野地板の取り合い部から火炎貫通 したため、安全性を考慮して 45 分時に加熱を終了した。C1 は加 熱 40 分時に熱映像により火炎貫通箇所が $200^{\circ} \mathrm{C}$ を超えたことを 確認し、44.5 分時には面戸板裏面中央部の熱電対 (C1-(2) が $160^{\circ} \mathrm{C}$ に達した。C2 (2),(4)）は加熱 45 分時まで室内側温度が $91^{\circ} \mathrm{C} に$ 留まり、遮熱性の規定を超えなかった（図 9)。

\section{1 面戸板裏面の補強仕様について（A3、A4）}

既存面戸板（木材 $12 \mathrm{~mm}$ 厚、垂木の面戸欠き無し）裏面一の補強 仕様についてその遮熱効果を考察する。加熱終了 50 分時の各仕様 の室内側温度は $\mathrm{A} 3$ (砂漆喰 $20 \mathrm{~mm}$ 厚塗り) が $98^{\circ} \mathrm{C} 、 \mathrm{~A} 4$ (木材 $30 \mathrm{~mm}$ 厚増し張り）が $81^{\circ} \mathrm{C}$ であり、加熱終了時の室内側温度に大きな差は なく、同様の遮熱効果が得られた（図 9 の A3・A4-(4)）。
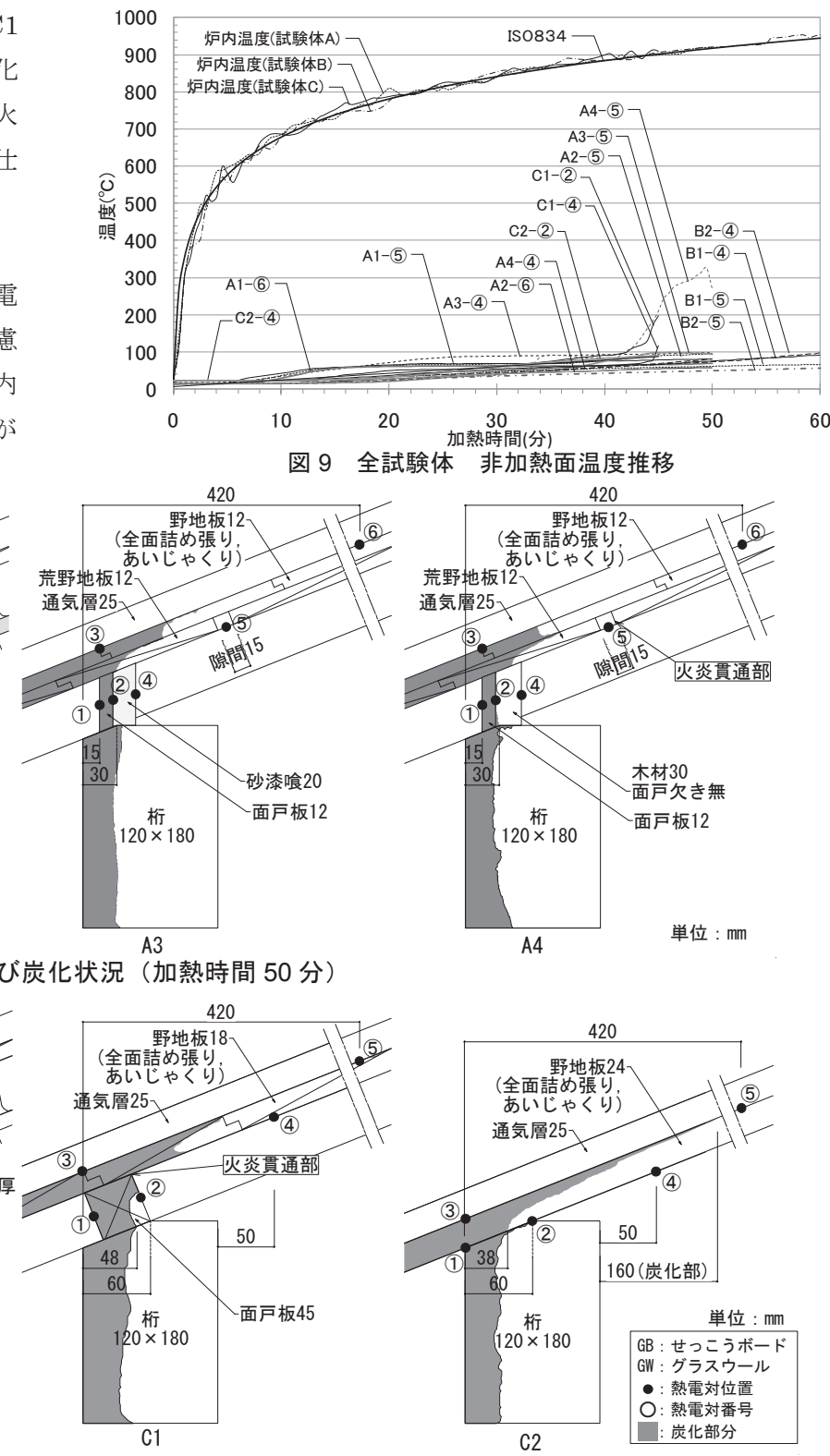

図 8 試験体 C 断面詳細及び炭化状況（加熱時間 45 分） 


\section{2 野地板の上面及び屋内面の補強仕様について}

（1）野地板上面の被覆仕様（A3、A4）

既存野地板 $12 \mathrm{~mm}$ 厚（室内側すかし張り）の上面に野地板 $12 \mathrm{~mm}$ 厚を重䇏りした $\mathrm{A} 3$ 及び $\mathrm{A} 4$ について考察する。A 3 は加熱 37 分、 $\mathrm{A} 4$ は加熱 30 分で図 10 の A3・A4-(3)が木材の着火温度である $260^{\circ} \mathrm{C}$ を超えた事より、野地板（総厚 $24 \mathrm{~mm}$ 厚）屋外側の下面より上面の 通気層一燃え抜けたものと推定される。A3 の野地板室内側温度は 加熱終了 50 分時には $94^{\circ} \mathrm{C}$ であったが（図 10 の A3-(5)）、加熱終了 直後に面戸板と野地板の取り合い部より火炎貫通が見られた。A4 の野地板室内側温度は加熱 46 分時に $260^{\circ} \mathrm{C}$ に到達し（図 10 の $\mathrm{A}^{-}$ (5)，加熱 50 分時には野地板下部の荒野地間隙間部から火炎貫通し た。つまり、野地板上部の通気層を通って桁表面より $120 \mathrm{~mm}$ 屋内 側にある野地板の隙間に火炎が到達する時間は、屋外側野地板が燃 え抜けてから 13〜16 分であることがわかる。以上より、既存野地 板の寸かし張りの有無によらず、既存野地板の上面に木材を全面詰 め張りし総厚 $24 \mathrm{~mm}$ とすることで、30 分を超える遮炎性及び遮熱 性を確保できる見通しが得られた。

（2）野地板屋内面の被覆仕様（A1、A2、B1、B2）

既存野地板 $12 \mathrm{~mm}$ 厚の屋内側に面材を張った $\mathrm{A} 1$ (垂木間に強化せ っこうボード $12.5 \mathrm{~mm}$ 厚張り)、A2（垂木間グラスウール充填十せっ こうボード $12.5 \mathrm{~mm}$ 厚張り)、B2（垂木間グラスウール充填十木材 $15 \mathrm{~mm}$ 厚張り）について考察する。いずれも加熱 $14 \sim 18$ 分で屋外側 野地板（詰め張り $12 \mathrm{~mm}$ 厚）の上面が $260^{\circ} \mathrm{C}$ を超え、野地板上部の 通気層へ延焼した（図 11 の $\mathrm{A} 1 \cdot \mathrm{A} 2 \cdot \mathrm{B} 2$-(3)）。加熱終了時の室内側温 度は $\mathrm{A} 1$ が $81^{\circ} \mathrm{C}\left(50\right.$ 分) $\mathrm{A} 2$ が $95^{\circ} \mathrm{C}$ (50 分)、 $\mathrm{B} 2$ が $97^{\circ} \mathrm{C}$ (60 分)であり、 3 仕様で同様の遮熱効果が得られた（図 11 の 1 1・A2-(5),B2-(4)）。

また、 $\mathrm{B} 1$ 及び $\mathrm{B} 2$ では室内側の桁を現しとするため、30mm 厚の 付桁を設けることで被覆材を天井面に留め付けた。しかし、付桁と 天井板の取り合い部は防火上の弱点となりや寸い。付桁と天井板の 接合部の裏面温度を図 11（B1・B2-(4)）に示す。両仕様とも加熱終 了 60 分まで接合部からの火炎貫通は見られず、裏面温度も $100^{\circ} \mathrm{C}$ に留まった。桁下までせっこうボード $12.5 \mathrm{~mm}$ 厚を張った A2 の加 熱終了 50 分時の接合部裏面温度 (A2-(5)) は $100^{\circ} \mathrm{C}$ であり、付桁を 用いた $\mathrm{B} 1$ 及び $\mathrm{B} 2$ と大きな差はなかった。以上より、桁を現しと する場合でも付桁 $30 \mathrm{~mm}$ 厚に天井仕上げ材を隙間なくはめ込む事 で、室内への遮炎性及び遮熱性を補完できる事が分かった。

\section{3 野地板上部の通気層の影響について}

屋根莫き材が瓦の場合、その納まり上、瓦と野地板の間に通気層 が生じ、野地板上部に貫通した火炎が通気層を通って棟方向へ延焼 する可能性が考えられる。

（1）野地板厚さの違い（A1、C1、C2）

野地板の厚さによる燃え抜け時間の違いを比較する。A1（詰め張 り $12 \mathrm{~mm}$ 厚）は 14 分、 $\mathrm{C} 1$ （詰め張り $18 \mathrm{~mm}$ 厚）は 22 分、 $\mathrm{C} 2$ (詰 め張り $24 \mathrm{~mm}$ 厚）は 26 分で屋外側の野地板上面が $260^{\circ} \mathrm{C}$ を超え、 野地板上部の通気層へ延焼した（図 12 の $\mathrm{A} 1 \cdot \mathrm{C} 1 \cdot \mathrm{C} 2$-(3)）。その後、 $\mathrm{C} 1$ は加熱 40 分時に屋内への火炎貫通が見られ、 C2 は 45 分以上の 遮熱性及び遮炎性が確保された（図 12 の $\mathrm{C} 2$-(2)）。また、詰め張り $12 \mathrm{~mm}$ 厚については加熱後約 20 分で屋内へ火炎貫通したことがわ かっている 1)。つまり、屋外側野地板が燃え抜けてから火災が通気 層を通り、屋内一燃え抜けるまでの時間は野地板が厚いほど長く、
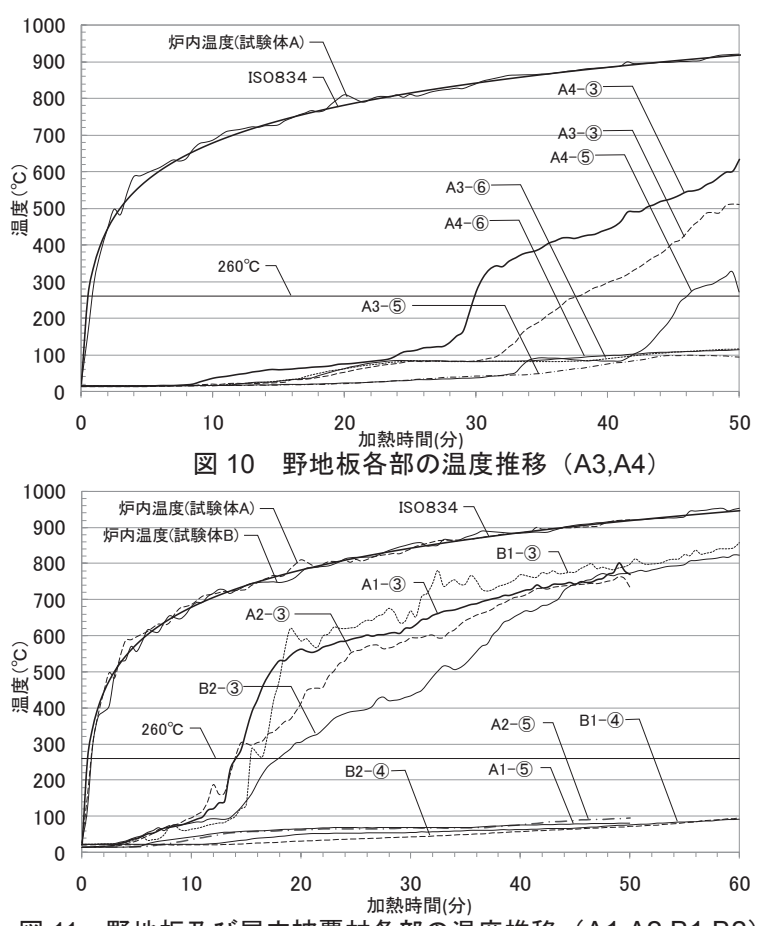

図 11 野地板及び屋内被覆材各部の温度推移（A1,A2,B1,B2）

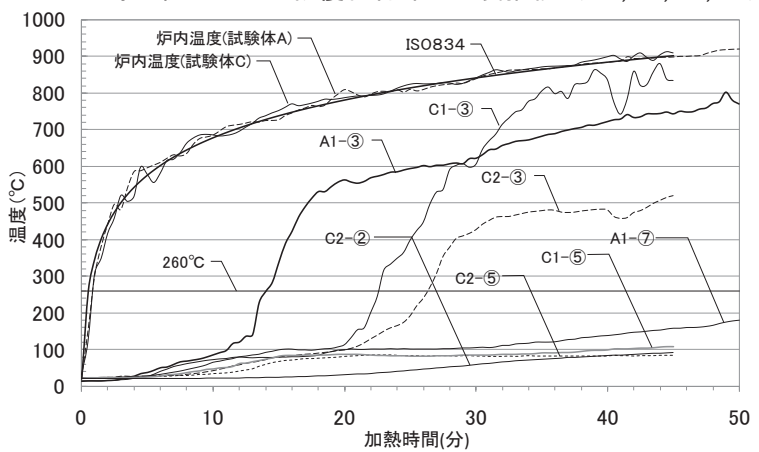

図 12 野地板各部の温度推移 $(A 1, C 1, C 2)$

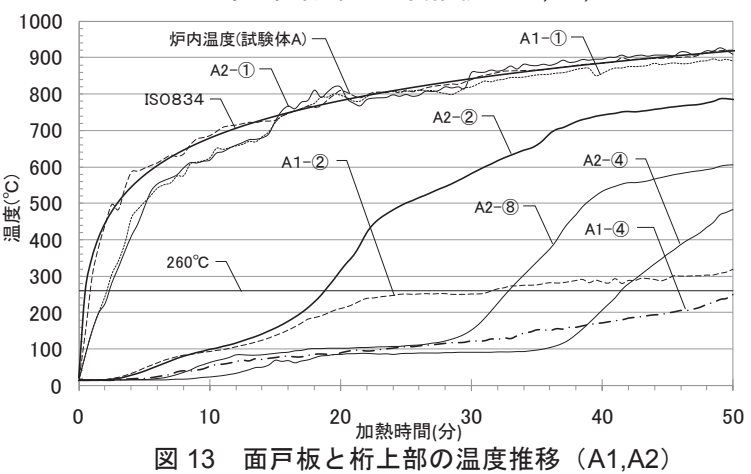

詰め張り $12 \mathrm{~mm}$ 厚が 6 分、詰め張り $18 \mathrm{~mm}$ 厚が 18 分、詰め張り $24 \mathrm{~mm}$ 厚が 19 分以上となることがわかった。

\section{（2）野地板補強範囲の検討}

図 6〜8 の炭化状況を見ると、屋外側野地板が上面へ然え抜け、 上部の通気層に火炎が侵入した後も、棟方向への急速な延焼拡大は 見られないことがわかる。また、桁表面より $420 \mathrm{~mm}$ 屋内側の野地 板上面の温度変化を見ると、火炎侵入後も急速な温度上昇は見られ ず、加熱終了時の温度は、A1（詰め張り $12 \mathrm{~mm}$ 厚）が $181^{\circ} \mathrm{C}$ (50 分)、C1 (詰め張り $18 \mathrm{~mm}$ 厚) が $107^{\circ} \mathrm{C}$ (45 分)、 C2 (詰め張り $24 \mathrm{~mm}$ 厚) が $84^{\circ} \mathrm{C}$ (45 分) であり（図 12 の $\mathrm{A} 1$-(7),C1·C2-(5)）、野地板上 部の通気層が屋内側への延焼防止上著しい悪影響を与える事はない 
といえる。以上を踏まえると、野地板は桁表面から $420 \mathrm{~mm}$ 屋内側 まで補強することで十分な防耐火性能が確保できることがわかった。

6.4 垂木間のグラスウール充填の有無について（A1、A2）

図 13 より、既存面戸板裏面温度はグラスウールを充填しない $\mathrm{A} 1$ (A1-(2) ) が加熱 32 分、垂木間にグラスウール (密度 $10 \mathrm{~kg} / \mathrm{m}^{3}, 50 \mathrm{~mm}$ 厚)を充填した $\mathrm{A} 2$ (A2-(2) ) が加熱 18 分で $260^{\circ} \mathrm{C}$ に達した。面戸板 の温度上昇は $\mathrm{A} 1$ では緩慢であるのに対し、A 2 では面戸板裏面がグ ラスウールで断熱される為、温度が早く上昇したと考えられる。そ の後、屋内被覆材に接する桁端部（A1·A2-(4)）の温度は、A1 では ゆるやかに上昇し加熱終了 50 分時は $249^{\circ} \mathrm{C}$ となり、 $\mathrm{A} 2$ では 36 分 頃に急速に温度が上昇し始め 41 分には $260^{\circ} \mathrm{C}$ に達した。また、桁 の炭化状況を見ると A 1 は桁表面より $40 \mathrm{~mm}$ 炭化しているのに対し、 $\mathrm{A} 2$ は $71 \mathrm{~mm}$ 内部まで炭化が進んでいる（図 6)。同様の傾向は垂木 間にグラスウールを充填した B1·B2 にも認められ（図 7)、グラス ウールを桁上方に充填したことにより桁上面からの熱損失が減少し、 桁の温度上昇と炭化が促進されたと考えられる。

\section{5 垂木の有無の影響}

C2 については垂木を用いないため、野地板と桁の接合部が防火 上の弱点となり易いが、加熱終了 45 分まで接合面からの火炎貫通 はなく裏面温度も $91^{\circ} \mathrm{C}$ に留まり（図 12 の $\mathrm{C} 2$-(2)）、45 分の遮熱性 及び遮炎性を確保した。図 8 を見ると加熱終了 45 分時には桁表面 より $38 \mathrm{~mm}$ 程炭化が進んでいたが、桁表面より $60 \mathrm{~mm}$ 屋内側まで トカド久きを施し、桁と野地板部の接合長さを確保したことが防火 上有効に働いたと考えられる。

\section{7. まとめ}

既存京町家の各種の改修・再生に適用可能な化粧軒裏の防火構造 の開発を目標に、計 3 体 8 仕様の試験体を用いた耐火加熱実験を行 い、各仕様で 30 分以上の遮熱性、遮炎性を有することを確認した。
改修方法に応じた各仕様を表 3 にまとめる。いずれの仕様も木材の 含水率を $16 \%$ 以下に管理し、部材間の接合部に隙間が生じない施工を することで表 3 に示す防耐火時間を確保した。

また、既存の各部位について以下の知見を得た。

(1) 既存面戸板（ $12 \mathrm{~mm}$ 厚以上）の屋内側に木材 $30 \mathrm{~mm}$ 厚以上、又 は砂漆喰 $20 \mathrm{~mm}$ 厚以上を補強すれば、面戸板周辺からの延焼を 50 分以上抑制できる。

(2) 屋根莫き材撤去後、既存野地板の上面に木材を全面詰め張りし総厚 $24 \mathrm{~mm}$ 以上とすれば、野地板上部への延焼を 30 分以上抑制できる。

(3) 既存野地板 ( $12 \mathrm{~mm}$ 厚以上) の屋内側にせっこうボード $12.5 \mathrm{~mm}$ 厚や木材 $15 \mathrm{~mm}$ 厚を張る事で室内側の遮熱性を 50 分以上確保で きる。また、垂木間にグラスウールを充填する場合も、グラスウ 一ルをせっこうボードや木材で被覆することで天井面の遮熱性を 補完できる。

(4) 野地板の補強は軒桁表面から $420 \mathrm{~mm}$ 屋内側まで施すことで、通 気層を介した延焼抑制に有効である。

[参考文献]

1) 安井昇, 長谷見雄二, 清水真理子, 木村忠紀, 田村佳英: 京町家様式の化粧軒裏 の各部仕様が火災時の遮熱・遮炎性能に及ぼす影響: 日本建築学会構造系論 文集,第 601 号, pp189-195, 2006 年 3 月

2）(財) 日本建築総合試験所: 防耐火性能試験・評価業務方法書（平成 22 年 6 月 1 日版）

3) 中嶋彩乃, 長谷見雄二, 安井昇, 鈴木あさ美, 木村忠紀, 門岡直也, 田村佳英: 化粧軒裏の簡易防火改修仕様の開発: 日本建築学会大会学術講演梗概集 (北 陸), A-2,pp121-122,2010 年

4) 門岡直也, 長谷見雄二, 安井昇, 鈴木あさ美, 木村忠紀, 田村佳英: 化粧軒裏の 簡易防火改修仕様の性能: 日本建築学会大会学術講演梗概集 (関東), $\mathrm{A}-2$, pp125-126,2011 年 [謝辞]

本実験は、トステム建材産業振興財甩助成「伝統的建築材料の防火性能の 測定とデータベース化」(代表者: 長谷見雄二) 及び平成 22 年度国交省地域 木造住宅市場活性化推進事業（事業主体：京都府建築工業協同組合）の一環 として実施した。本実験を行うにあたり、三菱東京 UFJ 銀行の中嶋彩乃氏 (実 験当時、早稲田大学大学院生)、京都府建築工業協同組合、(財) 日本建築総合 試験所、(株) 東亜理科の関係各位、並びに早稲田大学長谷見研究室の皆様に は多大なる御助言、御協力を頂きました。記して深く感謝の意を表します。

表 3 改修方法に応じた化粧軒裏防火改修仕様及び化粧軒裏告示仕様一覧

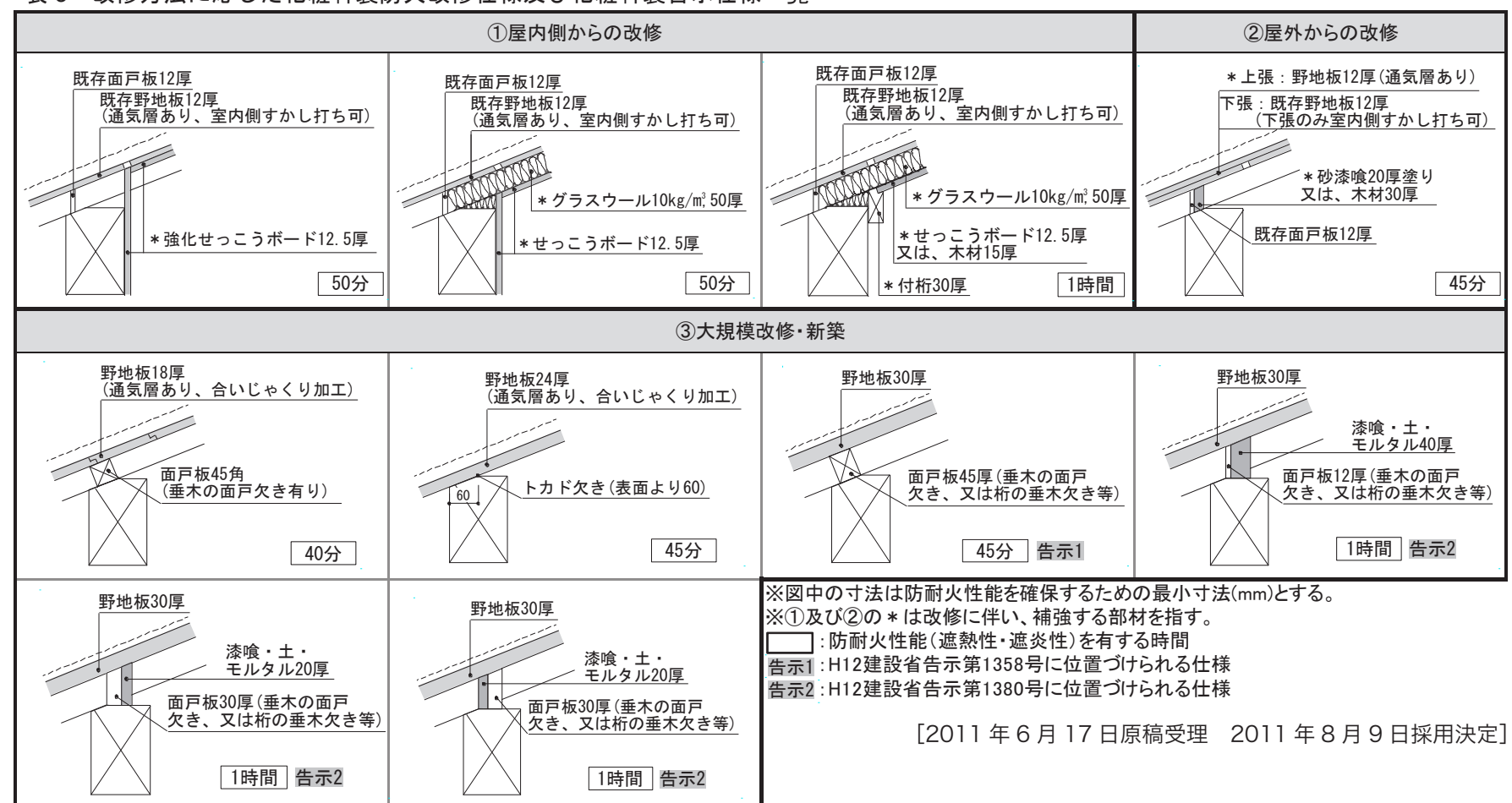

